приёмы можно активно совмещать. Главное правило изучения английского: не терзайте себя зазубриванием. Не надо часами сидеть за книгой и заучивать новые слова, которые через несколько дней забываются. Использование этих приемов на уроках английского языка обеспечивает поддержание интереса к предмету, к изучаемой теме, способствует лучшему запоминанию усваиваемого материала и в конечном итоге развивает память учеников.

$$
* * *
$$

1. Литвинов П.П «Как быстро выучить много английских слов»,Ступени к успеху.- М.: «АйрисПресс,2016г.

2. Ожегов С.И. Словарь русского языка: Ок.57000слов.-М.:Рус.яз,1984.-797с.

3. Подлиняев О.Л Эффективная память: учебное пособие. И.: Издательство ИГУ,2014-199с.

4. http://english99.ru/how-to-learn-english-words/

5. http://englishgu.ru/angliyskie-kartochki/

\title{
Zenkov A.V., Zenkov M.A. \\ Digging the Digits: the Novel Method of Text Attribution based on the Numerals Statistics
}

doi: $10.18411 /$ spc-26-07-2020-07

Ural Federal University

(Russia, Ekaterinburg)

idsp: sciencepublic-26-07-2020-07

Two approaches to the statistical analysis of texts are discussed, both based on the study of numerals occurrence in coherent literary texts. The first approach is related to the analysis of the frequency distribution of various first significant digits of numerals occurring in the text. These frequencies are unequal: the digit 1 is strongly dominating; usually, the incidence of subsequent digits is monotonically decreasing. Distribution of the first significant digits of the end of $\{1,2, \ldots, 8,9\}$ series is subject to strong fluctuations and unrepresentative for our purpose. The frequencies of occurrence of the digit 1 , as well as, to a lesser extent, the digits 2 and 3, are usually a characteristic author's style feature, consistently manifested in all (sufficiently long) literary texts of any author, which is confirmed by statistical tests. This approach is convenient for quick testing whether a group of texts has common authorship: the latter is dubious if the frequency distributions are sufficiently different.

The second approach is the extension of the first one and requires the study of the frequency distribution of numerals themselves (not their first significant digits). The approach yields non-trivial information about the author, stylistic and genre peculiarities of the texts and is suited for the advanced study of authorial texts.

The first of the two approaches can be considered a convolution of the latter.

The proposed approaches are illustrated by examples of computer analysis of the literary works in Russian, English, Latin, and Lithuanian.

The starting point of our study is Benford's law [1] which refers to the probability of occurrence of a certain first significant (leftmost nonzero) digit in the distributions of various real life data. The first significant digit of seemingly random numbers often fails to follow a flat distribution with an equal proportion of $1 \mathrm{~s}, 2 \mathrm{~s}, \ldots, 9 \mathrm{~s}$, as one would expect, but instead obeys a decreasing distribution, with more $1 \mathrm{~s}$ than $2 \mathrm{~s}$, more $2 \mathrm{~s}$ than $3 \mathrm{~s}$, and so on. According to Benford's law, probabilities of occurrence of the digit $d$ as first significant are as follows: 1 (0.301), 2 (0.176), 3 (0.125), 4 (0.097), 5 (0.079), 6 (0.067), 7 (0.058), 8 (0.051), 9 (0.046).

A classic experiment by Benford showing a good agreement with his law is the analysis of the occurrence of numerals contained in articles of a randomly selected issue of a magazine. Note that Benford himself analyzed the occurrence of numerals expressed only using figures. 
A conclusive explanation of Benford's law, covering all cases of its manifestation, is still absent, although some conditions favouring its emergence are stated. Incomplete understanding does not preclude the successful use of Benford's law to detecting fraud in accounting data and election fraud; the applications suggested extend from physics and astronomy to steganography and scientometrics.

We have shown the efficacy of counting frequencies of different 1 st significant digits of numerals for text attribution [2, 3]. It was found that not only for the random combination of heterogeneous texts, but also for the coherent Russian- and English-language texts, frequency distribution resembles that of Benford's law, but the quota of digit 1 considerably exceeds 0.3 - at least since the word 'one' formally being a numeral can actually play the role of the indefinite article. The frequent tendency of rounding numbers is also of importance.

In contrast to the traditional methodology of application of Benford's law, which treats deviations from the law as an indication of the possible existence of 'falsification' (broadly defined), we laid emphasis on the comparison of Benford-like distributions for texts by different authors, showing that the differences between these distributions are statistically robust author features that allow to distinguish between texts by different authors (the texts should be sufficiently large, about $200 \mathrm{~Kb}$ or more).

Following these ideas, we present here new research results concerning the distribution of 1st significant digits of numerals contained in coherent Russian-, English-, Latin-, and Lithuanian-language texts. The study is empirical and experimental in nature. The aim of the theoretical explanation of the results (if at all possible) is not intended; this, however, does not preclude the applicability of the suggested methodology for problems of stylometry.

For all (Russian-, English-, Latin-, and Lithuanian-language fiction) texts subjected to computer-aided statistical analysis, we have studied the frequency of occurrence of various 1 st significant digits of numerals, taking into account cardinal as well as ordinal numerals expressed both with figures, and (considerably more often) verbally. In the last case, the first step was to rewrite every form of a numeral with figures (e.g., "one thousand, one hundred and forty-seventh" replaced by "1147") and then to pick out the 1 st significant digit (in this example, the digit 1). To identify the author's use of numerals, we previously deleted from the text idiomatic expressions and set phrases accidentally containing numerals (like 'one hand washes the other', 'five-o'clock' in English), as well as itemizations like 1), 2), 3), etc.

Some of our results (confirmed by statistical tests):

1. Harper Lee's authorship of the novel «To Kill a Mockingbird» is proven (there existed the opinion that Truman Capote had ghosted Lee's book).

2. Ruth Plumly Thompson is shown to be the author of «The Royal Book of Oz» (initially, the book had been ascribed to L.F. Baum but some facts aroused doubts in his authorship).

3. The statistical peculiarities of the «Novel with Cocaine» («Роман c кокаином») by M. Ageyev are far from those of Vladimir Nabokov's novels (by virtue of a certain genre and stylistic proximity, the «Novel with Cocaine» had been earlier ascribed to Nabokov).

4. A well-known problem of texts attribution is the question of authorship of the novel «And Quiet Flows the Don» («Тихий Дон») and, more broadly, the entire literary heritage of M. Sholokhov. Our analysis shows that the «Virgin Soil Upturned» («Поднятая целина») and «They Fought for their Country» («Они сражались за Родину») could have been written by the same author, but probably, «Quiet Flows the Don» has a different authorship, and this authorship is not solitary. 
5. We analysed the novels «Three Parts of the World» («Три страны света») and «The Dead Lake» («Мёртвое озеро») written by N. Nekrasov, much better known as a poet, together with A. Panayeva. The manuscripts have not been preserved, so the question of the division of labor between the coauthors should take into account their own testimonies. In Panayeva's «Memoirs» («Воспоминания»), writing «Three Parts of the World» is ascribed to the two - both Nekrasov and her; as for «The Dead Lake», the participation of Nekrasov must have been limited to the elaboration of the plot and writing a small part of the text. Guided by philological considerations, literary scholars - contrary to Panayeva's testimony - discern in both novels a substantial part of the text by Nekrasov (with indication of specific chapters). Our statistical analysis shows that there is no reason not to trust Panayeva in her testimony about the process of writing her two joint novels with Nekrasov.

6. It would seem that our analysis requires the numerals not coinciding with indefinite articles (like ein in German and $u n$ in French). But we have analyzed a number of texts by English-language authors that have been widely translated into Russian. The statistical characteristics of originals and translations turned out to be very close. Thus, for the languages mentioned above, one can use the translations to an intermediary language - e.g. to Russian - instead of the originals.

7. Starting from the above analysis of statistics of the first significant digits of numerals, we now make a further step to the analysis of the use of numerals themselves in the authorial (Russian-, English-, Latin-, and Lithuanianlanguage) texts [4]. The first of the two approaches can be considered a convolution of the latter. Each approach has its advantages and disadvantages:

i. The analysis of the statistics of the first significant digits is only applicable to the significant digits 1,2 , and 3 , since the occurrence of subsequent digits is subject to strong fluctuations even in the texts of the same author. Thus, only a small part of the statistical information on the numerals contained in the text is available for analysis.

ii. On the other hand, the information here is presented in a generalized form, allowing to smooth the specific occasional features of numerals usage in individual texts by the author.

iii. Analysis of the use of the numerals themselves (and not the first significant digits) gives a richer information about an author's peculiarities of the text and, to a large extent, is not blocked by indistinguishability of the numeral one and the indefinite article.

iv. However, the analysis of numerals statistics is more difficult.

8. Using the extended analysis of numerals, we investigated the hypothesis [5] that I. Ilf and E. Petrov are fake authors of the novels "The Twelve Chairs" and "The Little Golden Calf", and they were ghosted by M. Bulgakov. The frequency distribution of numerals, as well as its cluster analysis, do not confirm this hypothesis.

We believe that our methodology can be a useful addition to the traditional textual practices of taking into account the length of sentences and words, counting the occurrence of service words and certain significant parts of speech, etc. 
The results obtained using the neural networks can be impressive, but the technique itself unfortunately is a 'black box': a clear interpretation of the results is usually difficult. In this sense, our approach seems linguistically more meaningful.

Acknowledgement

The work was supported by a grant from the Russian Foundation for Basic Research, project No. 19-012-00199A, "A New Method of Text Attribution Based on Statistics of Numerals"

\section{$* * *$}

1. Benford F. The law of anomalous numbers, Proc. of American Philosophical Society, 1938. Vol. 78, p. 551-572.

2. Zenkov A.V. A Method of Text Attribution Based on the Statistics of Numerals, J. of Quantitative Linguistics. 2018, Vol. 25, No. 3, p. 256-270.

3. Zenkov A.V., Místecký M. The Romantic Clash: Influence of Karel Sabina over Mácha’s Cikáni from the Perspective of the Numerals Usage Statistics, Glottometrics, 2019, Vol. 46, p. 12-28.

4. Zenkov A.V. Statistics of Numerals in the Text: Development of a New Method of Stylometry, First International Volga Region Conference on Economics, Humanities and Sports (FICEHS 19). Paris, Atlantis Press, Advances in Economics, Business and Management Research, 2019, Vol. 114, p. 448451.

5. Амлински И. 12 стульев от Михаила Булгакова. - Berlin: Kirschner Verlag, 2013. - 328 c. ISBN: 9783-00043-284-2. 